\title{
Structure and Contextual Meaning Analysis of Anecdote Text with Character and Local Wisdom as an Alternative to Selection of Teaching Materials for Indonesian in Senior High School
}

\author{
Endah Dyah Wardani' ${ }^{1}$, Rustono², Agus Nuryatin ${ }^{3}$ \\ ${ }^{1,2,3}$ Department of Language Education Science, Graduate School, UNNES, Indonesia \\ ${ }^{1}$ Corresponding email: idewardani09@gmail.com
}

\begin{abstract}
This study aims to describe (1) the structure and contextual meaning of anecdot texts containing local characters and wisdom; (2) anecdot as a medium of conveyance of character-filled thoughts and local wisdom; and (3) anecdotes text characters with local characters and wisdom into bahasa Indonesia materials in high school. This research is descriptive type using a qualitative approach. Research data in the form of anecdotal texts containing characters and local wisdom in Indonesia and have been validated by anecdot experts. The results of this study are (1) Of the 111 anecdotes, 75 items are complete anecdotes and 26 are structured anecdotes are incomplete whereas the textual meanings contained in anecdote texts that contain local characters and wisdom include: 1) collocative meaning; 2) reflective meaning; 3) stylistic meaning; 4) affective meaning; and 5) interpretive meaning; (2) Anecdotes are aptly used in the delivery of character and local wisdom because of the humor that students love and are easily accepted by students, the values contained in the text, and the stories of famous personalities; and (4) 89 anecdot texts were found from 111 anecdotal texts that were suitable to be used as teaching materials of bahasa Indonesia in senior high school.
\end{abstract}

Key words: Meaning, Function, Anecdote Text, Character, Local Wisdom

\section{Introduction}

The paradigm of learning bahasa Indonesia in the 2013 curriculum is text-based. With textbased expectations can be used in the formation of religious attitudes, social, knowledge, and skills.

Indonesian learning materials applied in class $\mathrm{X}$ contain several texts, including text reports on observations, expositions, complex procedures, negotiations, and anecdotes. Based on the results of observations made in Senior High School 13 of Semarang in the even semester of 2017 of the five types of text, the most attractive texts from students is anecdot text. This is because new anecdot texts appear in the 2013 curriculum. However, there are still many anecdot learning texts ranging from production to evaluation.

Anecdotes are interesting short stories because they are funny and impressive. An anecdote is a means of delivering messages and criticism of social phenomena through the packaging of funny stories but full of meaning. Sensitivity to the phenomena that occur in the community is very good as an Indonesian language learning material for students at school.

The selection of anecdot text as the object of this research is because anecdot texts have structure and textual and contextual meaning that are important to be understood by students so that they can master the competencies in the 2013 curriculum. In addition, anecdotal texts are new, so that this research is needed. The use of character anecdotes and values of local wisdom as teaching materials is very important.

\section{Method}

This study uses qualitative descriptive research approach. The four stages in analytical research are Unitizing, Sampling, Reducing data or simplifying data, and Abductively inferring (conclusions taking, as well as Naratting (narration) of answers to research questions. Anecdot texts are analyzed started from type, structure, textual meaning, contextual meaning, and the function of anecdotal texts in conveying information that contains characters and local wisdom in anecdote texts.

The data in this study are anecdot text containing character and local wisdom. 111 anecdote texts containing local characters and wisdom were selected and validated by linguists and anecdote experts. The researcher analyzes anecdote texts with functional pragmatic discourse analysis, then describes them systematically.

To know the type, structure, function, and meaning of the text, the researcher used the method of agih, which is the method that the determining tool is part of the language in question, that is the form of written discourse 
formed by using the language. The basic technique used is the technique for the direct element that is the way used at the beginning of the analytical work by dividing the lingual unit of data into several parts or elements, and the elements concerned are viewed as the direct part forming the lingual unit in question. Therefore, the discourse was analyzed in the form of fragments of discourse consisting of clauses and sentences.

\section{Results and Discussion}

The researchers found 276 anecdote texts from online media, prints, anecdote texts produced by students, anecdote texts scattered from social media, and from anecdote collection books. Not all anecdote texts contain character and local wisdom. After being validated by experts consisting of anecdote and language experts. Only 111 anecdotes were selected according to the research needs of anecdotes containing characters and local wisdom.

Character that appear in this research is character based on Law number 20 year 2003 about National Education System explain the function of national education is developing ability and forming character and civilization of dignified nation in order to educate nation life; and the purpose of national education to develop the potential of learners to become human beings who believe and cautious to God Almighty, noble, healthy, knowledgeable, capable, creative, independent, and become citizens of a democratic and responsible.

From that value, anecdotal texts validated by experts with character content include 1) religious spiritual, 2) self-control, personality, and noble character, 3) intelligence, and 4) social skills.

The important local wisdom content instilled into the learners includes 1) compassion, 2) wisdom, 3) a strong person, 4) humble, and 5) good at communicating. Based on the criteria, anecdote texts are selected and validated by experts. The following are the details of anecdote texts that have been validated by experts.

The number of anecdote texts containing the most characters with intelligence is 45 anecdote texts. Intelligence values are mostly in the form of information and discussion of characters in anecdote dialogue. The anecdote text with the least characters found is an anecdote text with self-control, personality, and noble character. Researchers only found six (6) anecdote texts. This is because only few people have compiled anecdote texts about noble character.

The number of anecdote texts containing the most local wisdom are as many as 14 anecdote texts. The value of compassion is found a lot because more writers tell about suffering or social criticism in society to become anecdote text. The anecdote text contains local wisdom of humility. The researcher only found three anecdote texts. This is because only few people who have compiled anecdote texts about humility.

\section{Anecdote Texts as Enrichment of Teaching Materials in Senior High School}

Based on the analysis only 89 anecdote texts from 111 anecdotal texts are worthy of being used as bahasa Indonesia teaching materials in senior high school.

The function of anecdote texts containing characters and local wisdom still refers to the basic functions of anecdotes, namely as entertainment media because they are funny or humorous. However, more than that, anecdotes have more complex language functions. Based on the results of anecdote text analysis of character and local wisdom, there are known five anecdote's functions. These functions include informative, expressive, directive, estetik, and fatik functions. In learning of bahasa Indonesia learning in high schools, all five functions are very important.

For example, in anecdote text (10) entitled "Presidential Chat".

""Because I was tired of traveling around the world, Gus Dur tried to find the atmosphere on the RI-01 plane. This time he invited the US and French President to fly with Gus Dur for a world tour. May dong, emangnya US and France wrote a presidential plane. As usual ... every president always wants to show off what his country is proud of. Not long after the American president, Clinton took out his hand and a moment later he said: "Wow, we're up in New York!"

Indonesian President (Gus Dur): "Why do you know?"

"That .. the statue of Liberty hold!", Clinton replied proudly.

Not wanting to lose to the French president, Jacques Chirac took his hand out. "You know ... we are above Paris!", He said arrogantly. 
President of Indonesia: "Wow ... how come you know too?"

"That ... the Eiffel tower holds!", Said the French president.

Because he was bragged with Clinton and Chirac, it was Gus Dur's turn to stick his hand out of the plane ... "Wow ... we are above Tanah Abang!!!", shouted Gus Dur.

"How come you know?" Clinton asked and Chirac was surprised because he didn't know Gus Dur could see.

"This ... my watch is gone ...", replied Gus Dur calmly. "

$$
\text { (DATA 8) }
$$

Based on the anecdote text (10), the language function that appears is an informative function. Informative function on the text in the form of information to the reader about the condition of Indonesia is like many cases of theft like in Tanah Abang. Sentence "My watch is gone" shows that in Indonesia especially Tanah Abang, there are still many such incidents. In addition, the information given by the author to the reader is the icon of the countries in the text such as America which is famous for the "Statue of Liberty" and France which is famous for the "Eiffel Tower". The expressive function is realized by the writer's desire to express disappointment towards the condition of the Indonesian economy which is still chaotic with the many thefts that occur. The directive function is indicated by the desire of the author to influence the reader to be able to see the reality in Indonesia and make the reader aware that the country of Indonesia is still improving in economic matters so that it can be known by other countries in the form of tourism or the icon is not a negative atmosphere. Therefore, this anecdotal text becomes a problem to the government and law enforcers to do more to handle cases that are rife in the community. Not only theft but also large-scale theft such as corruption also happens in Indonesia. Aesthetic functions are indicated by the selection of relaxed language that is often used in everyday conversation is the art of language contained in the text of the anecdote. For example, the sentence "How come you know?" Even though this came out from the character of Gus Dur, the President of the Republic of Indonesia, but the sentence was very comfortable in the reader because it was in the Indonesian context. Another example in the sentence "" This ... my watch is missing. "Gus Dur replied calmly." The sentence also shows that Indonesian language is reinforced by the word "calm" which shows a friendly Indonesian culture. Based on the anecdotal text (10), the language function that emerges is an informative function. Informative functions on the text in the form of information to the reader about the condition of Indonesia are still many cases of theft like in Tanah Abang. Sentence "This ... my watch ilang" shows in Indonesia especially Tanah Abang many such incidents. In addition, the information given by the author to the reader is the icon of the countries in the text such as America which is famous for the "Statue of Liberty" and France which is famous for the "Eiffel Tower". The expressive function is realized by the writer's desire to express disappointment towards the condition of the Indonesian economy which is still chaotic with the many thefts that occur. The directive function is indicated by the desire of the author to influence the reader to be able to see the reality in Indonesia and make the reader aware that the country of Indonesia is still improving in economic matters so that it can be known by other countries in the form of tourism or the icon is not a negative atmosphere. Therefore, this anecdotal text becomes a problem to the government and law enforcers to do more to handle cases that are rife in the community. Not only theft but also large-scale theft such as corruption occurred in Indonesia. Aesthetic functions are indicated by the selection of relaxed language that is often used in everyday conversation is the art of language contained in the text of the anecdote. For example, the sentence "How come you know?" Even though this came out from the character of Gus Dur, the President of the Republic of Indonesia, but the sentence was very comfortable in the reader because it was in the Indonesian context. Another example in the sentence "" This ... my watch is missing ..." Gus Dur replied calmly." The sentence also shows that the Indonesian language is reinforced by the word "calm" which shows the culture of Indonesian people who are friendly.

The fatik function is shown by the author using a familiar language so that readers of all circles can accept the intent to be conveyed through the anecdote text. If you see the meaning and intent that the author wants to convey, the anecdote text can be categorized into anecdote text with characters on the spriritual value. Context speaker of Gus Dur as an Indonesian cleric who became President must 
understand that the value of religion like stealing is prohibited. The author's message through Gus Dur's character is very strong and hit.

\section{Conclusion}

From the results of research and discussion, it can be concluded that, firstly, the textual meaning of anecdote text can be known from the form of the text that forms a whole anecdote. 111 anecdote texts that contain characters and local wisdom have high communication intensity. The type of text that mostly composes anecdotes is satire, paradoxal, and collocative texts. Whereas the textual meanings contained in anecdote texts that contain local characters and wisdom include collocative meaning, reflective meaning, stylistic meaning, affective meaning, interpretive meaning. Secondly, the contextual meaning of anecdote texts that contain characters and local wisdom in this research is influenced by addressors (emotive), message (poetic), contact (phatic), context (referential), and addressee (conative). Thirdly, the function of anecdote text as a medium for communicating character and local wisdom is a) as a character communication medium, text anecdotes are packaged to motivate personal and society to do something or not do something.; and b) as a medium for communication of local wisdom, the text of anecdotes is packaged to influence the person and society to find wisdom in life.

Based on these conclusions, suggestions that can be given by researchers include: 1) teachers are suggested that they can use anecdote text with characters and local wisdom as teaching materials in teaching anecdote text in schools; 2) students should use anecdote text in enriching anecdote text material in school learning and be able to understand the meaning of anecdote texts containing the characters and local wisdom the author conveyed through anecdote text; and 3) for researchers and observers of language, this research can be used as a reference in analyzing anecdote text using a functional pragmatic approach that has not been applied in previous research, especially on anecdote anecdote text analysis of character and local wisdom.

\section{References}

Kemendikbud. 2013. Bahasa Indonesia Ekspresi Diri dan Akademi SMA/MA/SMK/MAK Kelas X. Jakarta: Kemendikbud.

Rokhman, Fathur. 2014. Character Education for Golden Generation 2045 (National Character Building for Indonesian Golden Years). Procedia Social and Behavioral Sciences. 141: 1161-1165

Rustono. 1999. Pokok-pokok Pragmatik. Semarang: IKIP Semarang Press.

Schiffrin, Deborah. 1994. Approaches to Discourse. USA: Blackwell Publishers.

Searle, J.R .1969. Speech Acts: An Essay in the Philosophy of Language. Cambridge: Depdikbud

Silanoi, Ladda. 2012. The Development of Teaching Pattern for Promoting the Building up of Character Education Based on Sufficiency Economy Philosophy in Thailand. Procedia Social and Behavioral Sciences. 69: 1812-1816. 